\title{
Examination of the interval between litters (IBL) of different genotype HLW sows using survival analysis
}

\author{
1 Ágnes Baginé Hunyadi - ${ }^{1}$ Szilvia Kusza - ${ }^{2}$ Péter Balogh \\ ${ }^{1}$ University of Debrecen, Faculty of Agricultural and Food Sciences and Environment Management, \\ Institute of Animal Science, Biotechnology and Nature Conservation, Debrecen, Hungary \\ ${ }^{2}$ University of Debrecen, Faculty of Economics and Business, \\ Institute of Sectoral Economics and Methodology, Debrecen, Hungary \\ hunyadi@agr.unideb.hu
}

SUMMARY

In this study our aim was to find out if there is a difference between the genotypes determined for the previously identified mutations of seven genes of the Hungarian Large White in terms of the time spent in production. We identified the previously determined alleles of the seven genes (BF, EGF, ESR, FSH , H2AFZ, LEP, PRLR) related to proliferation that were and performed the survival analysis between breeds indicating the risk of culling and the time spent in production on the given farm. Based on the results of survival analysis by Log-rank test, Breslow (Generalized Wilcoxon) and Tarone-Ware test we concluded that they indicated a significant difference in case of the genes BF (Breslow and Tarone-Ware tests) the EGF (Log-rank and Tarone-Ware tests) and ESR (Log rank test) based on which the curves of the survival of the certain genes varied form one another significantly.

Keywords: pig, survival analysis, polymorphism, genes

\section{ÖSSZEFOGLALÁS}

Vizsgálatunk során arra a kérdésre kerestünk választ, hogy a magyar nagyfehér hússertés kocák hét gén már azonositott mutációira meghatározott genotípusai között van-e különbség a termelésben töltött idö hosszát tekintve. A szaporasággal összefüggö, korábban már azonositott gének (BF, EGF, ESR, FSHB, H2AFZ, LEP, PRLR) alléljait meghatároztuk, majd a fajták közötti túlélés elemzést elvégeztük, melyek a selejtezés kockázatát, a termelésben töltött idöt mutatták meg az adott gazdaságban. A túlélés elemzés Log Rank, Breslow (Generalized Wilcoxon) és Tarone-Ware tesztjének eredményeit alapján megállapitottuk, hogy a tesztek szignifikáns különbséget jeleztek a BF (Breslow and Tarone-Ware test), az EGF (Log Rank and Tarone-Ware test) és az ESR (Log Rank test) gének esetében, mely szerint az egyes genotipusok túlélési görbéinek lefutása jelentősen különbözött egymástól.

Kulcsszavak: sertés, túlélés analizis, polimorfizmus, gének

\section{INTRODUCTION}

Pork production is relevant internationally, in Europe as well as in Hungary. The aim at the development of domestic pork production involves the improvement of the organization, improvement and efficiency of production and meeting of the high quality standards of production. One way of improving pork production is the improvement of proliferation indicators.

In order to improve proliferation indicators pork producers use the new methods of researches in animal biotechnology and genetics, including MAS (marker assisted selection, GAS (gene assisted selection) and GS (selection based on genomic breeding value).

MAS identifies locuses in close relation to the gene coding the desired trait (Zöldág, 2012). The biggest advantage of marker based selection was found in case of traits at which traditional selection is less effective. This has a relevant role in swine husbandry. Marker assisted selection (MAS) enhances the exploration of the relations between the traits of reproductional biology (Zöldág, 2008).

The genomic map of swine has been created but the exploration of genes, markers and QTLs (Quantitative Trait Loci) is in progress. The exploration of the genetic information of genes that influence certain genes help breeders (Clop et al., 2003; Mindenková et al., 2010).
The swine production indicators can be improved through selection based on the specified study results. In addition, the focus is on certain group of traits such as proliferation related indicators (Uimari et al., 2011).

The genotyping of stocks enable us to make an optimal use of the genetic potential of individuals and provide the most suitable raising and feed conditions that best suit the needs of the breed. The exploration of the point mutations of reproduction-related genes (SNP) can be a selection criterion that results in the improvement of reproduction traits (Hidas, 2008).

Based on the reproduction biological processes the onset of mating ability, reproduction cycle, rate of impregnation, time of impregnation, proliferation, the raising performance, the interval between litters and the scale of culling of sows have to be considered. (Balogh and Novotniné, 2013).

The intervals between litters is a factor that influences considerably the productivity of sows. Since the proliferation-related indicators are a basic component of the economy of pig farms, the intervals between litters is not only an important indicator in terms of organization and efficiency but it is also a major economic factor. The determination of the life performance of sows as exactly as possible, the extent of culling and the date of the time of culling result in a decrease of costs on the given farm. Survival analysis is a field of the probability 
theory and statistics and it is concerned with the lifespan of biological organisms. The method was first applied by Kaplan and Meier (1958) to compare the different medication methods of serious diseases, with the studied event being the death of a patient and its date was measured from the beginning of the medication. It is a module that is suitable to study survival periods used in medicine, biology and in every case in which high proportion of information is only partially available (,censored observation”). A general example of the case occurs when the occurrence of a final event, and the time until that are dependent variables but the time span of the study is fixed. If the purpose of the study is to determine the extent to which the research depends on the different explaining (risk) factors, the Cox proportional hazard model has to be applied. Cox (1972) grounded his model on the premise that the risk curve can be described as the product of one factor depending on monitoring time (basic risk curve) and the exponential curves of the explaining variables. The Cox model has already been used by many researchers to study the life performance of sows (Decaluwé et al., 2014; Balogh et al., 2015; Santos et al., 2015).

In this work our aim was to determine the time sows spent in production in order to plan sow rotation and the right time of culling. We genotyped the Hungarian Large White breed for the previously identified point mutations of seven genes related to proliferation and the intervals between litters were detected. The difference in the time of culling was determined by variance analysis of genotypes and survival analysis.

\section{MATERIAL AND METHODS}

\section{Step 1: Genetic studies}

Blood samples of 93 Hungarian Large White breed were used by us. The genomic DNA isolation was done based on the method by Zsolnai and Orbán (1999). The detection of simple nucleotide polymorphisms (SNP) was first achieved by polymerase chain reactions (PCR) then the sections containing the mutation of genes were successfully amplified.

Studied genes:

- properdin $(B F)$,

- epidermal growth factor $(E G F)$,

- estrogen receptor $(E S R)$,

- follicle-stimulating hormone- subunit beta $(F S H \beta)$,

$-\mathrm{Z}$ member of $\mathrm{H} 2 \mathrm{~A}$ histon family $(H 2 A F Z)$,

- leptin $(L E P)$,

- prolactin receptor $(P R L R)$.

In the next work session the restriction length polymorphism (RFLP) study was done with the restriction enzymes listed in Figure 1. and the conditions with the exception of the $E G F$ polymorphism where the allelespecific PCR (AS-PCR) method was used to identify the two alleles already described.

Figure 1: Characteristics of polymorphism studies

\begin{tabular}{|c|c|c|c|c|c|c|c|c|}
\hline \multirow[b]{2}{*}{$\mathbb{G}^{\circ}$} & \multirow{2}{*}{$\begin{array}{c}\text { Forward primer's } \\
\text { sequence } \\
\left(5^{\prime}-3^{\prime}\right)\end{array}$} & \multirow{2}{*}{$\begin{array}{c}\text { Reverse primer's } \\
\text { sequence } \\
\left(5^{\prime}-3^{\prime}\right)\end{array}$} & \multirow{2}{*}{$\begin{array}{l}\text { The length } \\
\text { of the } \\
\text { amplified } \\
\text { product } \\
\text { (bp) }\end{array}$} & \multirow{2}{*}{\begin{tabular}{|c|}
$\begin{array}{c}\text { Annealing } \\
\text { temperature }\end{array}$ \\
$\left({ }^{\circ} \mathrm{C}\right)$ \\
\end{tabular}} & \multirow{2}{*}{$\begin{array}{c}\text { Restriction } \\
\text { Enzyme }\end{array}$} & \multicolumn{2}{|c|}{ Size of allele } & \multirow{2}{*}{ References } \\
\hline & & & & & & A (bp) & B (bp) & \\
\hline$B F$ & $\begin{array}{l}\text { ACT GCT ATGACGG } \\
\text { TT ACACT CTCCG } \\
\end{array}$ & $\begin{array}{l}\text { TCCAAGAGCCACC } \\
\text { TTCCT GG }\end{array}$ & 390 & 60 & SmaI & $\begin{array}{l}237 \text { és } 153 \\
\text { (SmaI-) }\end{array}$ & $\begin{array}{c}390 \\
(\mathrm{SmaI}+)\end{array}$ & $\begin{array}{c}\text { Jiang \& Gibson } \\
\text { (1998) }\end{array}$ \\
\hline$E G F$ & $\begin{array}{l}\text { GAAACAATTCCCG } \\
\text { TGTTCTCT }\end{array}$ & $\begin{array}{l}\text { TCACTTCCACACC } \\
\text { TGTAACATCT }\end{array}$ & 875 & 54 & - & 1527 & 652 & $\begin{array}{l}\text { Mendezet al. } \\
\text { (1999) }\end{array}$ \\
\hline ESR & $\begin{array}{l}\text { CCTGTTTTTACAG } \\
\text { TGACTTTTACAGA } \\
\text { G }\end{array}$ & $\begin{array}{l}\text { CACTTCGAGGGTC } \\
\text { A GTCCAATTAG }\end{array}$ & 120 & 55 & PvuII & 120 & 55 és 65 & $\begin{array}{l}\text { Short et al. } \\
\text { (1997) }\end{array}$ \\
\hline$F S H \beta$ & $\begin{array}{l}\text { GTATACCAGGTCC } \\
\text { TAAG }\end{array}$ & $\begin{array}{l}\text { GTCTCGT ACACCA } \\
\text { GCTCCTT }\end{array}$ & 1650 & 60 & $\alpha$ TaqI & 1650 & 675 és 975 & $\begin{array}{c}\text { Linville et al. } \\
(2001)\end{array}$ \\
\hline$H 2 A F Z$ & $\begin{array}{l}\text { GGTGGTTTCTGCTG } \\
\text { TCTGG }\end{array}$ & $\begin{array}{l}\text { TCATGGCT GGTCG } \\
\text { TCCTAG }\end{array}$ & 333 & $57-60$ & Bsu15I & 158 és 175 & 333 & $\begin{array}{c}\text { Zhang et al. } \\
(2009)\end{array}$ \\
\hline$L E P$ & $\begin{array}{l}\text { TGCAGTCT GT CTCC } \\
\text { TCCAAA }\end{array}$ & $\begin{array}{l}\text { CGATA ATTGGATC } \\
\text { ACATTTCTG }\end{array}$ & 152 & 60 & Hinfl & $\begin{array}{l}84 \text { és } 68 \\
(\mathrm{C} \text { allél) } \\
\end{array}$ & $\begin{array}{c}152 \\
\text { (T allél) }\end{array}$ & $\begin{array}{c}\text { Neuenschwander et } \\
\text { al. (1996) } \\
\end{array}$ \\
\hline PRLR & $\begin{array}{l}\text { CGGCCGCAGAATC } \\
\text { CT GCT GC }\end{array}$ & $\begin{array}{l}\text { ACCCCACCTTGT A } \\
\text { ACCCATCATCC }\end{array}$ & 170 & 62 & Alu 1 & 127 & 35 és 92 & $\begin{array}{c}\text { Gajdócsi et al. } \\
(2008)\end{array}$ \\
\hline
\end{tabular}

Note: the separation of nucleic acids was done by electrophoresis.

Step 2: Survival analysis of genotyped sows for the interval between litters (IBL) considering the traits of measuring value

The basis of the analysis was the interval between litters selected from the traits related to proliferation of the sows. The SPSS 22.0 statistical software was used for the analysis. We studied the differences between alleles of different genes through single factor variance analysis, Kaplan-Meier analysis and the Cox proportional hazard model. The Chi-square test was applied to determine the difference between risk rates.

\section{RESULTS AND DISCUSSION}

\section{Result of a single variance analysis}

Based on Table 1. after performing the single factor variance analysis we can conclude that each genotype has different IBL traits. The Bonferroni test of the variance analysis (that we applied because of the varying numbers) indicated a significant difference between the genotypes $B F$ and $E G F$. For sows of the $\mathrm{BB}$ genotype of the propedrin gene the interval between litters was 13 days shorter than that of the AA genotype sows $(\mathrm{P} \leq 0.05)$. 
The introduction of IBL traits of three genotypes of the Hungarian Large White swine and the indication of significant differences

\begin{tabular}{|c|c|c|c|c|c|}
\hline Gene & Genotype & Total N & lsmean & SE & \\
\hline & AA & NA & NA & NA & \\
\hline \multirow[t]{3}{*}{$B F$} & $\mathrm{AB}$ & 26 & 173.70 & 4.56 & b \\
\hline & $\mathrm{BB}$ & 67 & 163.85 & 2.47 & $\mathrm{a}$ \\
\hline & AA & 6 & 159.18 & 4.15 & $a b$ \\
\hline \multirow[t]{3}{*}{$E G F$} & $\mathrm{AB}$ & 25 & 177.14 & 5.50 & $\mathrm{~b}$ \\
\hline & BB & 61 & 163.26 & 2.31 & $\mathrm{a}$ \\
\hline & AA & 23 & 159.67 & 2.17 & a \\
\hline \multirow[t]{3}{*}{$E S R$} & $\mathrm{AB}$ & 70 & 168.88 & 2.82 & $\mathrm{a}$ \\
\hline & BB & NA & NA & NA & \\
\hline & AA & 3 & 165.23 & 13.22 & $\mathrm{a}$ \\
\hline \multirow[t]{3}{*}{$F S H \beta$} & $\mathrm{AB}$ & 53 & 167.28 & 2.88 & $\mathrm{a}$ \\
\hline & $\mathrm{BB}$ & 37 & 165.75 & 3.70 & $\mathrm{a}$ \\
\hline & AA & 69 & 166.12 & 2.55 & $\mathrm{a}$ \\
\hline \multirow[t]{3}{*}{$H 2 A F Z$} & $\mathrm{AB}$ & 20 & 170.41 & 4.98 & $\mathrm{a}$ \\
\hline & $\mathrm{BB}$ & 4 & 155.84 & 11.02 & $\mathrm{a}$ \\
\hline & TT & 72 & 166.43 & 6.33 & $\mathrm{a}$ \\
\hline \multirow[t]{3}{*}{$L E P$} & $\mathrm{TC}$ & 18 & 165.41 & 6.33 & $\mathrm{a}$ \\
\hline & $\mathrm{CC}$ & 3 & 177.90 & 20.29 & $\mathrm{a}$ \\
\hline & AA & 40 & 167.04 & 4.02 & $\mathrm{a}$ \\
\hline \multirow[t]{2}{*}{ PRLR } & $\mathrm{AB}$ & 37 & 165.35 & 2.91 & $\mathrm{a}$ \\
\hline & BB & 16 & 168.41 & 4.85 & $\mathrm{a}$ \\
\hline
\end{tabular}

From the genotype of the epidermal growth factor the interval between litters for the AA sows was 43.5 days shorter compared to that of the BB genotypes and 24 days shorter than for $\mathrm{AB}$ individuals. The detection of the point mutation of the $B F$ gene revealed that the stock lacked AA genotype animals. The frequency of genotypes was $27 \%$ in case of heterozygous individuals and $73 \%$ with BB sows. The interval between litters for $\mathrm{AB}$ genotype sows was longer on the average with 9.85 days that that of $\mathrm{BB}$ sows $(\mathrm{P} \leq 0.05)$.

During the $E G F$ study we also detected alleles A and B. The studied Hungarian Large White stock included all the three genotypes. The frequency of genotypes for $\mathrm{AA}$ is $6.5 \%, \mathrm{AB}$ is $27 \% \mathrm{BB}$ is $65.5 \%$. According to these results ESR proved to be the most influential gene in terms of the interval between litters. The point mutations of ESR, FSH $, H 2 A F Z, L E P$ and $P R L R$ genes did not result in significant difference during the comparison of the intervals between litters of the Hungarian Large White. Results of the survival analysis of different genotype sows Figure 2. IBL traits of three genotypes of the Hungarian Large White and the indication of significant differences.

The culled genotyped individuals of the $B F$ varied from one another in case of both genotypes. The culling time of $\mathrm{AB}$ genotype individuals is about 230 days, for $\mathrm{BB}$ genotype ones it is 255 days. This means half of the Hungarian Large White BB genotype individuals lived at least for 250 days before they were taken out of production. Half of the individuals of the other genotype left production before 230 days (Table 2, Figure 3).

The medians of the ages for the three genotypes that were culled were different. EGF AA genotype individuals were the earliest to be culled (about 170 days). AB sows were taken out 60 days later (230 days) while BB sows were culled 90 days later (260 days) (Table 2, Figure 3).

In case of the two genotypes of ESR that were culled the median of the age was different. AA genotype individuals were the earliest to be selected (about 180 days). AB sows get out of production 35 days later (205) (Table 2, Figure 3).

The results of Log Rank, Breslow (Generalized Wilcoxon) and Tarone-Ware tests were published in Table 2. Based on the result we concluded that the tests indicated a significant difference in case of the genes $B F$ (Breslow and Tarone-Ware test), EGF (Log Rank and Tarone-Ware test) and ESR (Log Rank test), showing that the survival curves of certain genotypes varied significantly.

Figure 2: Medians and standard errors for survival time in different genotypes

\begin{tabular}{|l|c|r|l|l|r|l|l|l|}
\hline \multicolumn{3}{|c|}{$B F$} & \multicolumn{3}{|c|}{$E G F$} & \multicolumn{3}{|c|}{ ESR } \\
\hline & Median & S. E. & & Median & S. E. & & Median & S. E. \\
\hline BB & 158.0 & 1.4 & AA & 153.5 & 5.2 & AA & 157.5 & 3.9 \\
\hline AB & 171.0 & 3.0 & AB & 177.4 & 11.7 & AB & 159.0 & 3.1 \\
\hline & & & BB & 158.0 & 1.3 & & & \\
\hline
\end{tabular}

\begin{tabular}{|c|c|c|c|c|c|c|c|c|c|c|c|}
\hline \multicolumn{3}{|c|}{$F S H \beta$} & \multicolumn{3}{|c|}{$H 2 A F Z$} & \multicolumn{3}{|c|}{$L E P$} & \multicolumn{3}{|c|}{ PRLR } \\
\hline & Median & S. E. & & Median & S. E. & & Median & S. E. & & Median & S. E. \\
\hline AA & 157.5 & 8.4 & AA & 158.3 & 1.1 & $\mathrm{TC}$ & 156.5 & 5.6 & AA & 157.0 & 4.0 \\
\hline $\mathrm{AB}$ & 159.2 & 3.2 & $A B$ & 162,8 & 1.0 & $\mathrm{TT}$ & 158.6 & 2.2 & BB & 163.5 & 2.4 \\
\hline BB & 158.6 & 4.3 & BB & 148,8 & 14.0 & $\mathrm{CC}$ & 163.2 & 8.7 & $\mathrm{AB}$ & 158.0 & 1.1 \\
\hline
\end{tabular}


Table 2. Results of the different tests on survival analysis in case of the Hungarian Large White swine

\begin{tabular}{|c|c|c|c|c|}
\hline Gene & & $\begin{array}{c}\text { Log Rank } \\
\text { (Mantel- } \\
\text { Cox) }\end{array}$ & $\begin{array}{c}\text { Breslow } \\
\text { (Generalized } \\
\text { Wilcoxon) }\end{array}$ & $\begin{array}{c}\text { Tarone- } \\
\text { Ware }\end{array}$ \\
\hline & Chi-Square & 3.666 & 4.614 & 4.942 \\
\hline \multirow[t]{3}{*}{$B F$} & df & 1 & 1 & 1 \\
\hline & Sig. & 0.056 & 0.032 & 0.026 \\
\hline & Chi-Square & 7.389 & 5.008 & 6.619 \\
\hline \multirow[t]{3}{*}{$E G F$} & df & 2 & 2 & 2 \\
\hline & Sig. & 0.025 & 0.082 & 0.037 \\
\hline & Chi-Square & 4.8529 & 2.137 & 3.208 \\
\hline \multirow[t]{3}{*}{$E S R$} & $\mathrm{df}$ & 1 & 1 & 1 \\
\hline & Sig. & 0.028 & 0.144 & 0.073 \\
\hline & Chi-Square & 0.213 & 0.490 & 0.409 \\
\hline \multirow[t]{3}{*}{$F S H \beta$} & df & 2 & 2 & 2 \\
\hline & Sig. & 0.899 & 0.783 & 0.815 \\
\hline & Chi-Square & 1.017 & 1.885 & 1.403 \\
\hline \multirow[t]{3}{*}{$H 2 A F Z$} & $\mathrm{df}$ & 2 & 2 & 2 \\
\hline & Sig. & 0.601 & 0.390 & 0.496 \\
\hline & Chi-Square & 0.551 & 1.116 & 0.908 \\
\hline \multirow[t]{3}{*}{$L E P$} & $\mathrm{df}$ & 2 & 2 & 2 \\
\hline & Sig. & 0.759 & 0.572 & 0.635 \\
\hline & Chi-Square & 0.258 & 1.879 & 0.955 \\
\hline \multirow[t]{2}{*}{ PRLR } & df & 2 & 2 & 2 \\
\hline & Sig. & 0.879 & 0.391 & 0.620 \\
\hline
\end{tabular}

\section{Evaluation of results}

The novelty of our work is provided by a survival analysis that showed the differences of the Hungarian Large White genotypes. We haven't found any research dealing with this in the literature concerned with swine husbandry. Then method introduced by us showed that in order to have an optimal selection for reproduction, the analysis of the survival of genotypes is an efficient method. Individuals that carry advantageous traits related to point mutation in terms of the time spent in production were also evaluated. By this method not only the individuals of the best indicators can be selected but the ones which stay in production for the longest period can be found as well. This new approach on the evaluation of sows can contribute to the efficiency of the sector.
Figure 3: Kaplan-Meier curves showing significant differences in case of the alleles of different genes
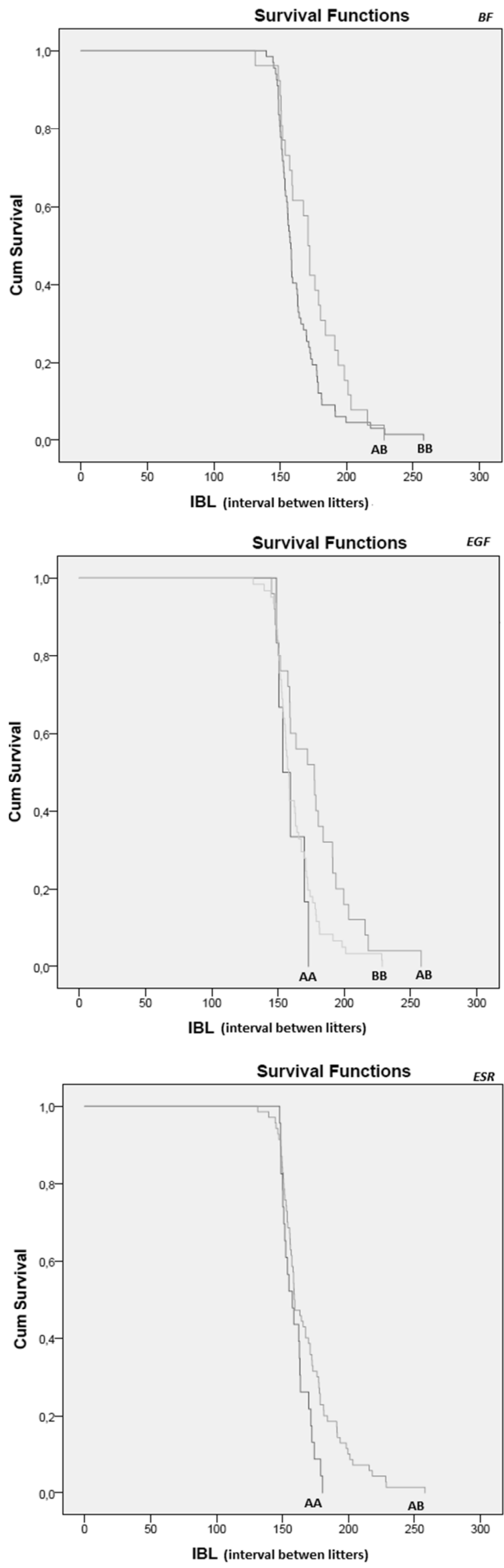


\section{REFERENCES}

Balogh, P.-Kapelański, W.-Jankowiak, H.-Nagy, L.-Kovacs, S.Huzsvai, L.-Popp, J.-Posta, J.-Soltész, A. (2015): The productive lifetime of sows on two farms from the aspect of reasons for culling. Annals of Animal Science. 15. 3: 747-758.

Balogh P.-Novotniné D. K. (2013): Versenyképes kocatartás és malacnevelés. Szaktudás Kiadó Ház. Budapest. 280.

Clop, A.-Óvilo, C.-Perez-Enciso, M.-Cercos, A.-Tomas, A.Fernandez, A.-Coll, A.-Folch, J. M.-Barragan, C.-Diaz, I.Oliver, M. A.-Varona, L.-Silio, L.-Sanchez, A.-Noguera, J. L. (2003): Detection of QTL affecting fatty acid composition in the pig. Mammalian Genome. 14: 650-656.

Cox, D. R. (1972): Regression models and life tables. Journal of the Royal Statistical Society. Series B (Methodological). 34. 2: 187-220.

Decaluwé, R.-Maes, D.-Wuyts, B.-Cools, A.-Pieper, S.-Janssens, G. P. J. (2014): Piglets' colostrum intake associates with daily weight gain and survival until weaning. Livestock Science. 162: $185-192$.

Gajdócsi E.-Pataki R.-Tempfli K.-Bali Papp Á. (2008): A prolaktin receptor gén hatása a mangalicák alomméretére. Animal Welthfare. 4: 424.

Hidas A. (2008): Molekuláris genetikai módszerek a háziállatok szelekciójában. [In: Tóth S.-Szalay I. A haszonállatfajok szelekciója.] Mezőgazda Kiadó. Budapest. 203-210.

Jiang, Z. H.-Gibson, J. P. (1998): Rapid communication: a PCRRFLP marker at the porcine complement factor B gene locus shows between-population frequency variation. Journal Animal Science. 76: 1716-1717.

Kaplan, E. L.-Meier, P. (1958): Nonparametric Estimation from Incomplete Observations. Journal of the American Statistical Association. 53. 282: 457-481.

Linville, R. C.-Pomp, D.-Johnson, R. K.-Rotschild, M. F. (2001): Candidate gene analysis for loci affecting litter size and ovulation rate in swine. Animal Science. 79: 60-67.

Mendez, E. A.--Messer, L. A.-Larsen, N. J.-Robic, A.-Rotschild, M. F. (1999): Rapid Communication: Epidermal Growth Factor Maps to Pigs Chromoseme 8. Animal Science. 77: 494-495.
Mindeková, S.-Trandzik, J.-Fecková, M.-Buleca, J.-Maróti J.Agóts R.-Massányi P.-Zöldág L. (2010): Az IGF2 gén genetikai struktúrája és variabilitása a szlovák házisertés fajtákban és a vaddisznóban. Magyar Állatorvosok Lapja. 132: 81-84.

Neuenschwander, S.-Rettenberger, G.-Meijerink, H.-Jorg, H.Stranzinger, G. (1996): Partial characterization of porcine obesity gene (OBS) and its localization to chromosome 18 by somatic cell hybrids. Animal Genetics. 27: 275-278.

Santos, V. S.-Martins Filho, S.-Resende, M. D. V.-Azevedo, C. F.Lopes, P. S.-Guimarães, S. E. F.-Glória, L. S.-Silva, F. F. (2015): Genomic selection for slaughter age in pigs using the Cox frailty model. Genetics and Molecular Research. 14. 4: 12616-12627.

Short, T. H.-Rothshild, M. F.-Southwood, O. I.-Mclaren, D. G.-De Vries, A.-Van der Steen, H.-Eckard, G. R.-Tuggle, C. K.-Helm, J.-Vaske, D. A.--Mileham, A. J.-Plastow, G. S. (1997): Effect of the estrogen receptor locus on reproduction and production traits in four commercial pig lines. Journal of Animal Science. 75: 3138-3142.

Uimari, P.-Sironen, A.-Sevón-Aimonen, M. L. (2011): Wholegenome SNP association analysis of reproduction traits in the Finnish Landrace pig breed. Genetics Selection Evolution. 43-42.

Zhang, Y. H.-Mei, S. Q.-Peng, X. W.-Zuo, B.-Lei, M. G.-Xiong, Y. Z.-Li, F. E. (2009): Molecular cloning and polymorphism of the porcine $H 2 A F Z$ gene. An International Journal of Animal Bioscience China. 779-782.

Zöldág L. (2008): A szaporaság genetikai alapjai emlős háziállatokban. Animal Welfare - Etológia és Tartástechnológia. 4. 2: 474-482.

Zöldág L. (2012): Állatorvosi genetika és állattenyésztéstan. Szent István Egyetem Állatorvostudományi Kar. Budapest.

Zsolnai, A.-Orbán, L. (1999): Accelerated separation of random complex DNA patterns in gels: comparing the performance of discontinuous and continuous buffers. Electrophoresis. 20: 1462-1468. 
